\title{
HEGEMONIC ANTAGONISTISM AS AN EMANCIPATIVE EFFORT IN DICKENS'S A CHRISTMAS CAROL (1843): A STUDY OF LACLAU- MOUFFE POST-MARXISM
}

\author{
Muhammad Surahman Djunuhi \\ Universitas Gadjah Mada, Indonesia \\ sudju01@gmail.com
}

Article accepted : July - $21-2020$

Revised article: November - $08-2020$

Approved article: November - 26 - 2020

Abstract

This study aims to describe the dominant hegemony and antagonism or contestation of hegemony that occurred in the novel A Christmas Carol (1843) written by Charles Dickens. The method is descriptive qualitative with note-taking data collection techniques. The results of the study prove are (1) Scrooge, a banker who from the beginning was and acted egocentric, individualist, and likes to exploit his employee, is the representation of the dominant capitalist hegemony. This domination has become the enemy and triggered the existence of humanist religiosity, counter-hegemony, or the people which are a hegemony collaboration of discourses of anti-exploitation, anti-discrimination, anti-egocentrism, and anti-individualism represented through social order and figures around Scrooge. (2) Scrooge's identity and ideology which is dominated by Capitalism hegemony are not full and dynamic. The lack of identity fullness gives a possibility to the transformation of identity and ideology in Scrooge. This is reinforced by the presence of antagonism of dominant hegemony, capitalism, and counter-hegemony, humanist religiosity that has implications for changing the attitude of Scrooge to become a rich person who is generous, religious, friendly, humanist, anti-exploitative, and antiindividual. Thus, the figure of Scrooge has become the arena of antagonism of hegemony in which the presence of hegemonic antagonism is an emancipatory effort countering and undermining the dominance of capitalism.

Keywords: Laclau, Mouffe, hegemony, antagonism, A Christmas Carol

\begin{abstract}
Abstrak
Penelitian ini bertujuan untuk menguraikan hegemoni dominan dan antagonisme atau kontestasi hegemoni yang terjadi di dalam novel A Cristmas Carol (1843) karya Charles Dcikens dengan menggunakan kajian post-marxisme Ernesto Laclau dan Chantal Mouffe. Metode yang digunakan adalah kualitatif deskriptif dengan teknik pengumpulan data simak-catat. Hasil penelitian membuktikan bahwa (1) Scrooge, seorang banker yang sejak awal bersifat dan bertindak egosentris, individualis dan suka mengeksploitasi pegawainya merupakan representasi dari hegemoni Kapitalis yang dominan. Dominasi hegemoni kapitalisme ini kemudian menjadi the enemy dan memantik eksistensi religiusme humanis, hegemoni tandingan atau the people yang merupakan kolaborasi dari wacana anti-eksploitasi, anti-diskriminasi, anti-egosentrisme dan antiindividualisme yang direpresentasikan melalui tatanan sosial dan tokoh-tokoh di sekitar Scrooge. (2) Identitas Scrooge yang didominasi oleh hegemoni Kapitalisme bersifat tidak penuh. Ketidakpenuhan ini memberikan kemungkinan akan transformasi identitas dan ideologi pada diri Scrooge. Hal ini diperkuat dengan hadirnya antagonisme hegemoni dominan, kapitalisme dan hegemoni tandingan, religiusme humanis yang berimplikasi perubahan perubahan sikap Scrooge menjadi orang kaya yang dermawan, religius, ramah, humanis, anti-eksploitatif dan anti-individual. Dengan demikian, tokoh Scrooge telah menjadi representasi arena antagonisme hegemoni. Kehadiran antagonisme hegemoni ini merupakan upaya emansipatif melawan dan meruntuhkan dominasi kapitalisme.
\end{abstract}

Kata kunci: Laclau, Mouffe, hegemoni, antagonisme, A Christmas Carol 
Poetika : Jurnal Ilmu Sastra

Vol. 8 No. 2, December 2020

\section{INTRODUCTION}

A Christmas Carol is one of the phenomenal works of Charles Dickens. This novel describes the atmosphere of the city of London from 1840 s to 1860 s which is very different from the views of people in general. Background of the feast of Christmas, the metropolis and industrial development of the all advanced in London covered by the 'dark side' London is revealed by Dickens. Those are the number of poor, misery, hunger, and cold society in this decade. A Christmas Carol included in the 100 best novels throughout the period in 1923. On the novel's 80th anniversary, The New York Times called the greatest little book in the entire world. BBC News noted that in the first edition of this novel in December 1843, Dickens spent six thousand copies of his own money to publish his book which was sold out in just five days. A Christmas Carol has become a best seller in the UK and America long before it was published the second time by The New York Times in 1851 because of none of the international copyright laws, so in popularity, Dickens did not produce any dime from the American edition. The dark side of the London setting and the storyline in A Christmas Carol have implications for Dickens's attempt to criticize the capitalists represented by the character Ebenezer Scrooge. He is a businessman who hired an employee, Bob Cratchit, all day to night for a low wage. He has a cold, stingy, aloof man and hates the poor.

"On one occasion, he was asked for a do-
DOI $10.22146 /$ poetika.56533

ISSN 2338-5383 (print) ; 2503-4642 (online)

nation by two men for poor people in London who also wanted to celebrate Christmas, but his response was very surprising."

"If they would rather die," said Scrooge, "they had better do it, and decrease the surplus population. (Dickens, 1834: 8).

Scrooge agrees with the suffering of the lower classes in London. In his mind, they deserve to die to reduce the excess population on the earth. From these events, we can surely see Dickens constructing a satirical conversation with the London capitalists who often 'dance' over the suffering of the poor. In the story, Scrooge was aware of the shackles of the principle of the capitalist. This happened after three spirits visited him and portrayed events in the past, the present, and the future of him. It made him ultimately aware of the meaning of happiness which is not from possession of money, but togetherness, sharing empathy, living happily together with the poor.

Here, in the process of awakening Scrooge, Dickens presents dialectic antagonistic and agonistic. The belief and the truth of class identity can be prone to change to social dialectics. The character Scrooge represents the high social class with the principles of capitalism meanwhile the majority of society around Scrooge represents the low social class which is the domination of anti-capitalist principles. However, the presence of each of these antagonistic identities is not full and provides free space for dialogue. This space aims to reach an agreement between groups of people, to create a 
kind of tolerant space for two classes, so they can see humans as friends not opponents without discriminatory preferences.

Thus, this study uses the concept of Ernesto Laclau and Chantal Mouffe's antagonism hegemony. This concept is based on the contestation of politically agonistic argument in creating free space for each conviction championed by community groups and leads to a political change and temporary agreement which is represented on the transformation of identity and ideology by certain individuals or groups as a consensus that is not full and susceptible to change. This can be seen in the character Scrooge. His wealth had made him not have the sensation of being happy but only have the gloom and worry of losing the wealth. The implication of this anxiety is the lack of identity in Scrooge's identity or capitalistic ideology. Then, it becomes an arena of contestation of hegemony manifested in Scrooge's social order then ignites the transformation of identity and ideology of rich capitalists to a philanthropist and humanist one.

Ernesto Laclau focused on the postmodern political sector and was also commonly referred to as a post-Marxian with his partner Chantal Mouffe (1943). Laclau-Mouffe uses Derrida's concept of deconstruction to revisit the effectiveness of the use of structuralist Marxian concepts that are no longer relevant in the development of a highly advanced capitalist culture today, namely that the present political arena has clouded our view to determining who is our opponent or friend (Haekal, 2019). This is very different from the conditions in the nineteenth to twentieth centuries in which knowledge of conflicting antagonistic dualities can be easily distinguished. They are the workers as emancipatory warriors and the owners of capital as conservatives who oppress the workers.

This antagonistic contestation led to the discovery where the subject of politics, which is a subject will never experience the fullness or will continue to have a lack in their social order. Laclau adopted the concept of the political subject from the concept of Lacanian psychoanalysis (Stavrakakis, 2007: 67). Laclau's idea also connects with Mouffe's who convinced the importance of conflict in a democratic space where conflict or antagonistic elements are an integral part of democracy (Martin, 2013:1). Nevertheless, the conflicts which they offer are agonistic (Laclau \& Mouffe, 2014), namely transforming the view of antagonistic or opposing "orthodox" relations into agonisticantagonistic relations. It is the wise way to see ideological or political opponents as being rivals, not enemies so that the democratic space offered by Laclau and Mouffe has become an emancipatory space, where the presence of conflicting political subject struggles is a struggle to reject the dominant identity and dominant discourse in this antagonistic space. The hegemony offered by Laclau-Mouffe is very different from Gramsci's conception of hegemony which tends to be a tool of the ruling class to gain popular approval in subordination pro- 
jects without resorting to violence or subtle approaches (Hutagalung, 2008: xii).

In the Laclau-Mouffe conception, antagonism plays an important role in producing a shift in identity and dominant hegemony, that is, antagonism will produce political opponents who play a major role in constructing clear and dichotomic political boundaries (Haekal, 2019). Collaboration and integration of this opposition group can also be called the common people in fighting the common ene$m y$. Thus, the antagonistic and agnostic space presented by Laclau-Mouffe will continue to produce emancipatory struggles, namely the eliminating dominant power, dominant identity, and fundamentalist and discriminatory discourse in agonistic conflicts.

To prove the renewal and to map the position of this research on existing research maps, the researcher conducted some literature reviews on previous related researches using Charles Dickens's A Christmas Carol as a material object, including the following. First, the article was written by Theresia Erwindriani with the title "Scrooge's Character Development in Charles Dickens' A Christian Carol". It aimed for investigating the character dynamics of the Scrooge character (Erwindriani, 2012).

Second, "Philanthropism in Charles Dickens's A Christmas Carol: A Genetic Structuralism Analysis", an article written by Rakhman et al. This study aims to uncover Dickens's global view through A Christmas Carol (Rakhman et al., 2015). Third, the article
"Religiosity in Charles Dickens' Novel a Christmas Carol Through Genetic Structural Method" written by Robert Juni Tua, et al. This research is intended to reveal the meaning and existence of religiosity in A Christian Carol (Sitio et al., 2018). Fourth, Savitri's thesis with the title "Formasi dan Negosiasi Ideologi: Kajian Hegemoni Gramsci terhadap A Christmas Carol karya Dickens". This study aims to reveal the relationship between ideological formations in the novel with Brits and the efforts of A Christian Carol as an instrument of negotiation in British society in the era of the french revolution at that time. Fifth, the article "The Analysis of Non-Literal Meaning in Christmas Carol by Charles Dickens" was written by Maria Salvatrix BB Nimanuho. This study intends to find the types of terms with non-literal meanings that exist in the novel A Christian Carol (Nimanuho, 2017).

The five studies are reassuring researchers to perform updates on the social dimension of the analysis presented in Dickens's A Christmas Carol. Laclau-Mouffe's Paradigm of agonistic antagonism based on of psychoanalyst, marxism, rhetoric and political elements into research analysis where a conflict that occurred in the Scrooge is no longer seen as "negative", but as a way of emancipatory which sparked collaborations hegemony of humanism and religiosity in undermining the domination of hegemonic capitalism that occurred within Scrooge. To elaborate more on this research related to the background above, the researcher asked two questions which will be discussed 
as follows, how is the dominant hegemony of the Scrooge character in the novel $A$ Christmas Carol and how is the hegemonic antagonism of the character Scrooge in producing Emancipation in A Christmas Carol.

\section{FINDING AND DISCUSSION}

\section{Scrooge Figures in the Grip of Capitalist He- gemony}

At the beginning of the novel $A$ Christmas Carol, the discourse or hegemony of capitalism seems so dominant. Thomassen (2016: 165) states that hegemony is built on the articulation of the relationship between social elements which can be referred to as a signifier and structured although it does not have a fixed or absolute meaning so that hegemonic articulation is open and has a very important position in political and economic movements. Hegemony, then, in essence, is not tied to a dominant or single class and identity by the rulers, but hegemony can also be an instrument of opposition groups against the ruler in articulating identity and triggering changes in the collective subject. The hegemony of Laclau-Mouffe is a combination of political concepts, psychoanalysis, and rhetoric in which each individual in society is regardless of class or economic background and can produce social change. It is represented by Scrooge's actions. He was a miserly and rich banker and often exploited his employees. This can be seen in the following quotation.
"Oh! But he was a tight-fisted hand at the grind-stone, Scrooge! A squeezing, wrenching, grasping, scraping, clutching, covetous, old sinner! Hard and sharp as flint, from which no steel had ever struck out generous fire; secret, and self-contained, and solitary as an oyster" (Dickens, 1834: 2).

Scrooge, in the above quotation, is described as an old sinner who is greedy, solitary, and cold-hearted. He seems so egocentric with his wealth. His greed for money made him reluctant to socialize, thus turning off his empathic ability to see, understand, and respond to his poor social order, full of poverty and suffering. This can be seen from the quotation below.

"Scrooge had a very small fire, but the clerk's fire was so very much smaller than it looked like one coal. But he couldn't replenish it, for Scrooge kept the coal-box in his room; and so surely as the clerk came in with the shovel, the master predicted that it would be necessary for them to part" (Dickens, 1834: 3).

The context of the quotation above is on a very cold Christmas Eve where everyone is ready to welcome Christian holidays by warming themselves and gathering with their family, but Scrooge still supervises his employee, Bob Crunchit, to keep working on that day. Not only that, the text above shows how stingy Scrooge was in spending his money. This is shown from the temperature of the fireplace which was so small, even the fireplace to warm Crunchit was no more than one small coal. Scrooge kept this supply of coal in his room so that his employee couldn't pick it up.

"It's not convenient," said Scrooge, "and it's not fair. If I was to stop half-a-crown for it, you'd think yourself ill-used, I'll be 
bound?"

The Clerk Smiled Faintly.

"And yet," said Scrooge, "you don't think I'm ill-used when I pay a day's wages for no work."

The clerk observed ed that it was only once a year (Dickens, 1834: 10).

The dialogue above is the conversation between Scrooge and his employees after Crunchit closed their office. A conversation that shows Crunchit's wish to be given a day off once a year, namely on Christmas Day to gather with his family. However, Scrooge refused, Scrooge did not want to pay the full day with the energy used half a day or not at all in a day. This shows Scrooge's actions which have been hegemonized by the principles of capitalism, where he often exploited his employee without the slightest empathy. Christmas day is the birthday of the loving Jesus Christ, but unfortunately, Scrooge has no love and affection for those around him. He really hated Christmas Eve. Scrooge's Christmas spirit which is based on zero affection has been blinded by money. In his mind, he only liked to find various efforts to maintain wealth and to increase his coffers of money.

The wealth possessed by Scrooge does not indicate the achievement of happiness and serenity in his life. The anxiety about losing his wealth truly has sparked him to lack the confidence and warmth in socializing with anyone who will only produce wasted time.

"What else can I be," returned the uncle, "when I live in such a world of fools as this? Merry Christmas! Out upon merry Christmas! What's Christmas time to you but a time for paying bills without money; a time for finding yourself a year older, but not an hour richer (Dickens, 1834: 4).

Not only the employees but also the cold treatment, insults, and discrimination was done by Scrooge against his nephew. The text above is a dialogue between Scrooge and his nephew, Fred, who wanted greetings to Scrooge. However, Scrooge always responded to these words with a ' humbug ' or bragging sign, as if Christmas greetings with a happy expression were happiness in the mask of suffering or lies behind. Scrooge also insulted his nephew, who kept increasing money but didn't seem the least bit richer than before. Scrooge's action shows the strong tension gap between classes. Even though, it is his nephew, social level and class are the reasons for Scrooge to be at odds and a barrier to their social relations in harmony and collaboration as a family, even if they are fellow humans.

The text above also shows the gloom that adorns Scrooge's life which is represented by Fred's questions and statements to Scrooge, that even though Scrooge has enough money, why he seems so gloomy and difficult to have fun enjoying his life. The gloom and anxiety in Scrooge's life show implications for selfenriching actions without a sense of adequacy. It indicates that Scrooge's self-fulfilling identity as a rich person in the grip of capitalism's hegemony. This then shows Scrooge's lack of identity as a capitalist, so that the shift of Scrooge's 
principle and identity is possible in the arena of antagonism based on political, rhetorical, and agonistic hegemony. This shift in subjectivity is caused by the presence of dislocation which is the highest ontological horizon of human discourse and construction, so that the lack of a subject is not completely negative, but also productive to identify something original, namely the lack of identity experienced by the subject (Laclau \& Zac, 1994: $3)$.

Dialogue between Fred and Scrooge and between Crunchit and Scrooge may have implications for the antagonism of hegemony. This antagonism produces a shift in identity and dominant hegemony, that is, antagonism will produce political opponents who play a major role in constructing clear and dichotomic political boundaries (Haekal, 2019). The hegemony of capitalism dominant shown Scrooge is so self-centered, individualistic, exploitative, oppressive, and discriminatory against the discourse of humanism and religionism which are constructed by Crunchit and Fred. In this case, the capitalistic upperclass form Scrooge's identity formed by capitalism with dominant hegemony has become the common enemy for humanism and religiosity represented by Crunchit and Fred.

\section{Emancipatory Struggle and Collapse of Capitalism as Dominant Hegemony}

In this hegemonic contestation, religiousism or Christian belief is represented in the form of ghosts and spirits who succes- sively visit Scrooge on Christmas Eve. This begins with the presence of the ghost of his banker friend, Jacob Marley, pictured in the quote below.

"It is done to wander through the world oh, woe is me! - And witness what it cannot share, but might have shared on earth, and turned to happiness!"

The specter raised a cry, and shook its chain, and wrung its shadowy hands.

"You are fettered," said Scrooge, trembling. "Tell me why?"

"I wear the chain I forged in life," replied the Ghost (Dickens, 1834: 22).

The text above describes the meeting and dialogue between the ghosts of Marley and Scrooge. Scrooge seemed so scared and was disturbed by the presence of Marley with a transparent figure and a chain wrapped around him. Marley told his duty after death, namely to warn everyone who was still alive, including Scrooge, to repent and share happiness with everyone. The chain that shackled Marley's body was a form of punishment for her negative actions, sins while living in the world. The presence of the ghost of Marley explains the intervention of God in the belief religiousism, it is a life after death and the time of vengeance upon every human action while living in the world. Religion here becomes a hegemony that is so strong in influencing the identity and principles of capitalism that Scrooge has.

The presence of the Marley ghost here makes Scrooge scared, but it seems Scrooge has not been able to imagine and realize what he will face after death. Therefore, on the same night, he was again visited by three Christmas 
spirits at different times. The first spirit will bring Scrooge to look back on his past, the second spirit will bring Scrooge to the present and the third spirit will bring Scrooge to see what will happen in his future.

It opened before them, and disclosed a long, bare, melancholy room, made barer still by lines of plain deal forms and desks. At one of these, a lonely boy was reading near a feeble fire; and Scrooge sat down upon a form, and wept to see his poor forgotten self as he used to be. (Dickens, 1834: 33)

The text above describes Scrooge's journey and the spirit of the first Christmas that brought Scrooge to his past. Scrooge saw himself as a lonely and poor little boy in a sad room. The situation that was witnessed greatly made Scrooge sad at what he had felt in the past, but on the other hand, his memory of his past made him realize that he had been poor, felt suffering without anyone. His family had ignored him, only his sister who care and love him, but Scrooge reciprocates the affection with contempt and hatred at his sister's son, Fred.

"You ho, my boys!" said Fezziwig. "No more work to-night. Christmas Eve, Dick. Christmas, Ebenezer! Let's have the shutters up," cried old Fezziwig (Dickens, 1834: 36).

The past Christmas spirit, in the above quotation, then shows Scrooge's adolescence working in a warehouse with his good friend, Dick Wilkins. They have a manager, Fezziwig who is kind and so attentive to them. Fezziwig forbade them from working on Christmas Eve and allowed them to have fun and to feel the warmth of the togetherness of Christmas. At this time, teenage Scrooge looks so cheerful and has a Christmas spirit to share togetherness and happiness with Wilkins and Fezziwig. This event reignited old Scrooge's awareness as past when he ever lived cheerfully with a strong Christmas spirit. He also missed the Fezziwig who was friendly, cheerful, sociable, anti-exploitative, and generous to everyone, all leadership traits that old Scrooge lacked.

After that, at different times on the same night, Scrooge is visited by the spirit of the present Christmas. The spirit brings Scrooge to visit the poor people around Scrooge. One of them is a home employee, Bob Cratchit with his family, Mrs. Cratchit, and six children. They were so poor with dull and shabby clothing. They ate mediocre food although they were still able to enjoy the simple happiness at Christmas.

"God bless us every one!" said Tiny Tim, the last of all. He sat very close to his father's side upon his little stool. Bob held his withered little hand in his, as if he loved the child, and wished to keep him by his side, and dreaded that he might be taken from him" (Dickens, 1834: 56).

They have been happily enjoying Christmas Eve together however, the Cratchit family has some worries. The quotation above depicts Cratchit's anxiety for one of his children, whose name is Tiny Tim, who is sickly and dying. All the events and sensations of the Christmas celebration at Cratchit's house were witnessed by Scrooge who was accompanied by the second spirit of Christmas. This gave the impression of 
Scrooge who hated Christmas and the poor before him.

"No, no," said Scrooge. "Oh, no, kind Spirit! say he will be spared. " "If these shadows remain unaltered by the Future, none other of my race," returned the Ghost, "will find him here. What then? If he is like to die, he had better do it, and decrease the surplus population. " Scrooge hung his head to hear his own words quoted by the Spirit, and become penitence and grief" (Dickens, 1834: 56).

After observing what happened, Scrooge, in the above quotation, immediately asked the Christmas spirit about the future that what happened with Tiny Tim. Then, the spirit replied, there is a gloom that will come to the Cratchit family, Tiny Tim will die when Cratchit's poor situation does not change. As quoted in Scrooge's previous statement, Tim's death was better at reducing the surplus population. Suddenly, this statement startled Scrooge and then touched his empathy which was filled with sadness and regret. He regretted his actions that had exploited his poor employee, even on Christmas Day Scrooge still forced Cratchit to keep working, because he didn't want his money to go out for nothing. The sadness and regret here become a strong marker as a trigger for a shift from the lack of identity as a rich capitalist. The dominant capitalist hegemony within Scrooge begins to be degraded by the presence of counter-hegemony (namely Christian discourse, anti-exploitative discourse, humanist discourse, and anti-individual dis- course) that is based on the unfortunate, touching, and empathic events that Scrooge witnessed at the Cratchit family home.

On the last Christmas spirit's visit, Scrooge is taken to a place with an atmosphere that is still unfamiliar to him, the situation that awaits him in the future. The events he witnessed seemed to be in an unknown city. It was the day a man had died, but he received a shocking response from many people who hated him because of his miserly, greedy, and anti-social attitude as long as he lived.

"He thought if this man could be raised now, what would be his foremost thoughts? Avarice, hard dealing, griping cares? They have brought him to a rich end, truly! He lay, in the dark empty house, with not a man, a woman, or a child, to say that he was kind to me in this or that, and for the memory of one kind word I will be kind to him. A cat was tearing at the door, and there was a sound of gnawing rats beneath the hearth-stone" (Dickens, 1834: 77).

The quotation above shows Scrooge witnessed the death of this person without anyone beside him crying over his departure forever. No one, friends, children, wives, friends, even relatives attended and cared about his death. As if his existence in the world does not mean anything to everyone around him. There were animals only who accompanied his body at a dark home without "an alive human". It certainly makes Scrooge more sacred and conscious of the life after death, not punishment is only given by God to travel around the world with a vision to remind those who live to repent like the ghost of Marley. However, Scrooge also realizes that his evil actions during life have conse- 
quences for social punishment like the dead man, one of which is that no one cares about his death, even celebrating his death in happiness.

"Good Spirit," he pursued, as down upon the ground he fell before it: "Your nature intercedes for me, and pities me. Assure me that I yet may change these shadows you have shown me, by an altered life! " The kind hand trembled. "I will honor Christmas in my heart, and try to keep it all the year. I will live in the Past, the Present, and the Future. The Spirits of all Three shall strive within me" (Dickens, 1834: 84).

The above quotation confirms the dead man in loneliness, without any attention from his relatives. This shows the lack of Scrooge's temporal identity. The lack of his identity as a rich man greatly affects the dominant hegemony of the capitalist that exist in his consciousness. His hatred of Christmas, an individual, exploitative, oppressive, and egocentric life have been shaken by Scrooge's statement to change into a better human being with a humanist spirit of religiosity, namely caring for fellow human beings without discriminating heir identity as the poor, or the rich. Scrooge has become a different person with a new identity. He became friendly, generous and wished everyone Christmas greetings, as in the quotation below.

"A merry Christmas, Bob!" said Scrooge, with an earnestness that could not be mistaken, as he clapped him on the back. "A merrier Christmas, Bob, my good fellow, than I have given you for many a year! I'll raise your salary, and endeavor to assist your struggling family, and we will discuss your affairs this very after- noon, over a Christmas bowl of smoking bishop, Bob!" (Dickens, 1834).

Scrooge changed drastically, in the above quotation, he greets his staff, Cranchit a Merry Christmas. He increased Cratchit's salary, even promising to help Cratchit's family life. This was triggered by his new and strong belief in the afterlife and social consequences for one's social actions at the time of death. Here it is increasingly clear that the antagonism is manifested in two major hegemony, namely the dominant capitalistic hegemony, and the counter-hegemony, namely the Christian humanist religiousism. The belief in reprisal for human deeds after death has become a marker of hegemonic efforts in almost all religions which helps the discourse of humanism to glow in Scrooge. This antagonism presents into Scrooge and becomes a new reflection until a new identity transformation is achieved, namely the rich who are anti-exploitative, anti-discriminatory, generous, friendly, anti-individual, and antihegemonic. This identity transformation explains the lack of identity in Laclau and Mouffe's concepts. The counter-hegemony based on religious and humanist principles has become an emancipatory effort against the dominant hegemony of capitalism that had previously gripped and shaped Scrooge's identity.

This counter-hegemony has become a collaboration of the particularities ideological contradictions against the ideology of capitalism, namely the particularity of anti-oppression, anti-exploitation, anti-discrimination, antiegocentrism, and anti-individualist. All of these 
went on in the identity of humanist religionism in Scrooge's social order. This is represented by a spirit that is a Christian belief as well as a medium in conveying all kinds of humanism hegemony and discourse of anticapitalism to Scrooge's character. The antagonisms here are also agonistic, where the conflicts that occur are hegemony based on rhetoric, politics, and psychoanalysis, namely hegemonic contestation to produce a new and better transformation of ideology and identity in Scrooge. Contestation of hegemony is the case in Scrooge's social order in the form of arguments about poverty, suffering, and death. The hiper-exploitation of capitalism then becomes Scrooge's reflection to produce a new identity, ideology, and "selfversion who cares of the poor with a religious and humanist spirit". This transformation of Scrooge's identity and ideology signifies the success of the emancipatory struggle from counter-hegemony based on the principles of humanist religiousism in undermining the domination of capitalism which has become the common enemy in Scrooge.

\section{CONCLUSION}

Based on the results of the above discussion, this research uncovers that Scrooge has been dominated by the hegemony of capitalism where he is not only a rich, egocentric, and individualistic man, but also likes to exploit his employee. Capitalism is the dominant hegemony that influences dominantly and constructs the identity of Scrooge as a rich man who is stingy, anti-empathic, aloof and anti-humanist, and anti-religious. Thus, capitalism as the dominant hegemony into Scrooge's identity has become the common enemy for humanist religiousism which becomes the people, the collaboration of the anti-oppressive, antiexploitative, anti-discriminatory, antiegocentric, and anti-individualist discourses. These are already represented through the social order and characters around Scrooge.

Then, the researcher found a lack of identity-based on the ideology of capitalism from Scrooge. This can be seen from the gloom of his life without the joy and anxiety that he continues to feel. These feelings signify a lack of identity from perfection and susceptibility to change of ideology and identity. This lack in Scrooge's self then becomes an arena for agonistic and hegemonic antagonism. This antagonism is a contestation of the dominant hegemony, capitalism, against the counter-hegemony, humanist religiousism, that occurs in Scrooge's social order. This humanist-religionism hegemony is a representation of the emancipatory struggle against the domination of hegemonic capitalism which was manifested in Scrooge's previous ideology and identity. The contestation of hegemony based on rhetoric and politics (in the concept of Laclau and Mouffe) implicates emancipatory actions that can ruin the domination of capitalism hegemony and the transformation of Scrooge's identity and ideology. Now, he becomes a generous, religious, friendly, humanist, anti-exploitative, and antiindividual man. Thus, Scrooge represents the 
antagonism hegemony arena constructed by

Charles Dickens for destroying domination of capitalism through counter-hegemony in A Christmas Carol's social order.

\section{REFERENCES}

Dickens, C. (1834). A Christmas Carol. London: Chapman \& Hall.

Erwindriani, T. (2012). Scrooge's Character Develpoment in Charles Dicken's A Christmas Carol. Celt: A Journal of Culture, English Language Teaching \& Literature, 12(1), 29-45. https:// doi.org/10.24167/celt.v12i1.3

Haekal, L. (2019). Subjek "Yang-Politik": Menafsir Subjek Politik pada PascaMarxisme Ernesto Laclau. JWP: Jurnal Wacana Politik, 4(2), 107-121. https:// doi.org/10.24198/jwp.v4i2.22565

Hutagalung, D. (2008). Hegemoni dan Demokrasi Radikal-Plural: Membaca Laclau dan Mouffe. In E. Laclau \& C. Mouffe (Ed). Hegemoni dan Strategi Sosialis: Postmarxisme + Gerakan. Yogyakarta: Resist Book.

Laclau, E., \& Mouffe, C. (2014). Hegemony and Socialist Strategy: Towards a Radical Democratic Politics. London: Verso Trade.

Laclau, E., \& Zac, L. (1994). Minding the Gap: The Subject of Politics. In Ernesto Laclau (Ed). The Making of Political Identities, (pp. 11-39). New York: Verso.

Martin, J. (2013). Chantal Mouffe: Hegemony, Radical Democracy, and The Political. New York: Routledge.

Nimanuho, M. S. B. (2017). The Analysis of Non-Literal Meaning in Christmas Carol by Charles Dickens. Jurnal Ilmiah Bahasa Dan Sastra, 4(2), 104-115. https:// doi.org/10.21067/jibs.v4i2.3182

Rakhman, F. A., Suwargono, E., \& Adiana, M. (2015). Philanthropism in Charles Dickens's a Christmas Carol: a Genetic Structuralism Analysis. Publikasi Budaya, 3(2), 25-30.

Sitio, R. J. T., Rasid, Y., \& Rahmat, A. (2018). Religiosity in Charles Dicken's Novel a Christmas Carol Through Genetic Struc- tural Method. Ijlecr-International Journal of Language Education and Culture Review, 4 (1), 1-7. https://doi.org/10.35940/ Ijeat.F1074.0986s319

Stavrakakis, Y. (2007). Lacanian Left. Edinburgh: Edinburgh University Press.

Thomassen, L. A. (2016). Hegemony, Populism and Democracy: Laclau and Mouffe Today. Revista Española de Ciencia Política, 1(40), 161-176 